\title{
宇宙環境が循環調節に及ぼす影響とその要因解明へのアプローチ 一衛生学における実験的研究の観点から一
}

\author{
青木 健 ${ }^{{ }_{1}}$, 小川洋二郎 ${ }^{{ }^{* 1}}$, 岩崎 賢一 ${ }^{{ }^{*} 1}$, 向井 千秋 ${ }^{*_{2}}$ \\ ${ }^{*}$ 日本大学医学部社会医学系衛生学分野 \\ ${ }^{*} 2$ 宇宙航空研究開発機構宇宙医学生物学研究室
}

\section{Approach to Elucidating the Influences and Factors Affecting Circulation System in Humans in Space Environment}

\author{
Ken AOKI ${ }^{* 1}$, Yojiro OGAWA ${ }^{* 1}$, Ken-ichi IWASAKI ${ }^{* 1}$ and Chiaki MUKAI ${ }^{* 2}$ \\ ${ }^{*}$ Division of Hygiene, Department of Social Medicine, Nihon University School of Medicine \\ ${ }^{*}$ Space Biomedical Research Office, Japan Aerospace Exploration Agency
}

\begin{abstract}
Many physiological changes associated with spaceflight, including decreases in orthostatic tolerance, exercise capacity, and blood volume have been reported. Orthostatic intolerance is a problem affecting many astronauts immediately postspaceflight. In particular, the relationship between orthostatic intolerance and cerebral autoregulation has been the focus of study in our research group. Although impairment of cerebral autoregulation was speculated to be one of the factors resulting in reduced post flight orthostatic tolerance, a 2 -wk spaceflight study revealed that human cerebral autoregulation is preserved or even improved during and immediately after spaceflight in nonsymptomatic astronauts. To investigate the influences of the different kinds of reduction in central blood volume, we performed two groundbased studies. It is suggested that the mild intravascular dehydration partly explains the improved dynamic cerebral autoregulation observed during and immediately after a short-term spaceflight. Moreover, we also studied the relationship between orthostatic intolerance and cerebral autoregulation under hyperthermic conditions, because hyperthermia leads to orthostatic intolerance. Furthermore, we planned to conduct a study at the International Space Station (ISS) and ground-based studies to elucidate the influences and factors affecting the circulation system in humans in a space environment.
\end{abstract}

Key words: space medicine (宇宙医学), orthostatic tolerance（起立耐性), cerebral autoregulation（脳循環 調節機能), dehydration (脱水), hyperthermic condition (高温環境)

はじめに

国際宇宙ステーション (International Space Station: ISS) に 2008 年春, 我が国初の独自有人宇宙施設である実験棟

受付 2011 年 3 月 25 日，受理 2011 年 4 月 7 日

Reprint requests to: Ken-ichi IWASAKI

Division of Hygiene, Department of Social Medicine, Nihon University School of Medicine, 30-1 Oyaguchi-Kamicho, Itabashi-ku, Tokyo 173-8610, Japan

TEL: +81(3)3972-8111 ext.2265, Fax: +81(3)3974-9131

E-mail: iwasaki.kenichi@nihon-u.ac.jp
「きぼら」が設置されて以来，今年で 3 年になる。その 間，日本からは若田，野口宇宙飛行士がこの宇宙ステー ションに拈いて長期滞在を行った。宇宙飛行中には, 地 球とは異なる環境要素 (微小重力環境, 宇宙放射線環境, 閉鎖環境など）に曝露され，特に宇宙空間での長期滞在 により，人間の身体には変化や適応が起こる。言い換觉 れば仮に運動などの対抗措置をとらず，単純に微小重力 環境へ長期間曝露されることで，骨格筋や心䇗の萎縮お よび循環血液量の減少などを生じ, 起立耐性は低下寸る。 その結果, 地上帰還直後, 立位姿勢をとった際に前失神 の症状を呈する現象を生じる場合が多くある。 
この帰還時における起立耐性低下ならびに前失神症状 の出現は, 仮に緊急脱出などが必要となった場合, 宇宙 飛行士の生命危機に直結する大きなリスクとなりらるこ とから, その予防法の確立や適切な対処策を探るらえで, その機序を明らかにすることは宇宙医学における重要な 課題の一つである。中でも我々の研究グループでは，こ の起立耐性低下に関係する要因の特定などについて，特 に循環系の指標に焦点をあてて，実験的手法を用い宇宙 と地上での両場面に捺いて基礎的研究を行っている。本 稿では，微小重力への曝露期間の違いによる脳循環調節 の変化とその要因，ならびに宇宙医学に基づいた起立耐 性低下への予防措置としての人工的温熱環境の利用やそ の影響について，衛生学に扣ける実験的手法を用いた研 究内容や成果ならびに今後の展望などを織り交ぜながら 解説する。

\section{起立耐性と脳循環調節}

起立耐性低下ならびにそれに伴う立位失神は，最終的 には脳血流の供給不足により症状が出現するが，そこに 至る機序には多くの要因が関係している。その要因の一 つとして，血圧変化を緩衝し脳に一定の血液を供給する 機構である「脳循環調節機能」の障害が考えられている。 そこで実際に宇宙での研究として，スペースシャトル Neurolab-Mission（STS-90）に打いて，2週間の微小重力 環境がヒトの脳循環調節系に及ぼす影響について検討さ れた（図 1）（1）。その結果，当初の予想に反して2 週間 の宇宙飛行中および帰還直後の脳循環調節機能は保持も しくは増強されることを報告している。この予想に反し た「脳循環調節機能の増強」は，宇宙飛行後に「体循環 系の障害」による起立耐性低下状態への代償反応として 生じている可能性がある。そこで，「2 週間の微小重力環 境曝露による脳循環調節機能の増強」といらこの研究結 果を受けて，我々の研究グループでは，何がこの様な脳 循環調節機能の変化をもたらす要因であるのかを特定す るための地上実験を体系的に実施してきている。

通常, 数週間の宇宙飛行を通じて, 心蔵周囲に分布す る血液の量を表す中心循環の血液量は劇的な変化を示 し，帰還時には顕著に減少する (2)。その際における血 液の性状としては, 主に血漿量減少に起因する血液濃縮 を伴った状態（脱水） $(2,3)$ と, 血球成分の減少も含め た全血液量が減少している状態 (4) とが認められる。

そこで我々の研究グループでは，短期間（1２週間 $)$ の宇宙飛行による中心循環の血液量減少を想定した二つ の地上実験を計画した。それぞれ，薬理的(利尿薬投与) に血漿成分のみの減少による血液濃縮を伴ら中心血液量 減少状態（脱水）をつくった実験 $(5,6)$ と, 物理的（下 半身陰圧負荷）に血球成分の減少も含めた全血液量の減 少を模擬した中心血液量減少状態をつくった実験（7）で ある。そして, 各々の実験に打いて中心循環の血液量減 少と脳循環調節機能の関係を検討した。

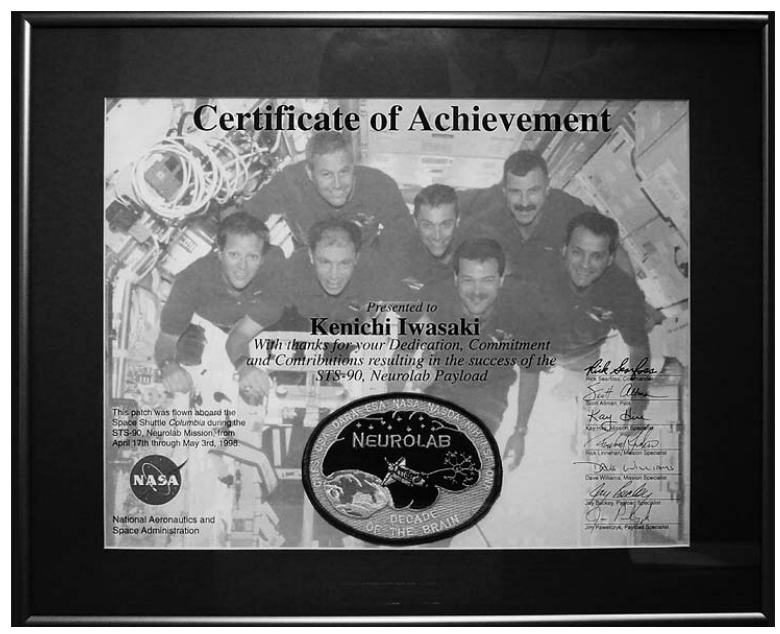

図 1 スペースシャトル Neurolab-Mission（STS-90）参加の NASA 宇宙飛行士より研究参加関係者に送られたミッション成 功に対する感謝状

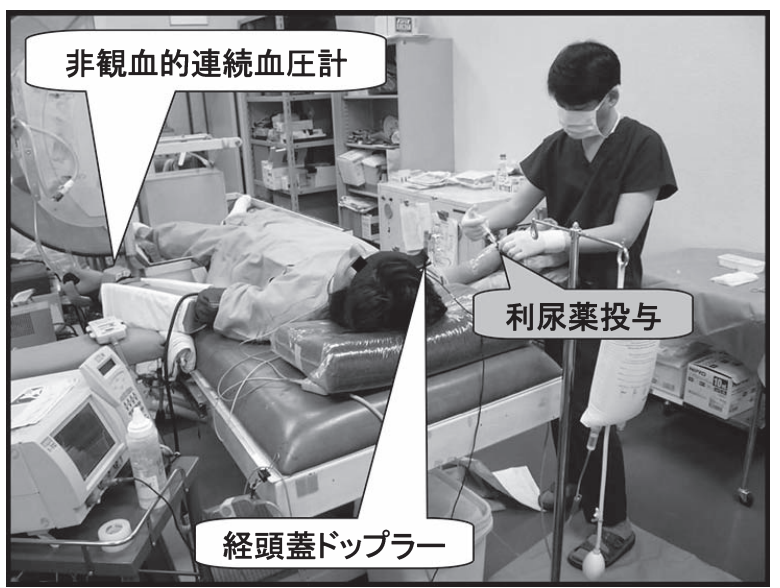

図 2 利尿薬投与による中心循環の血液量減少の実験風景

脱水に関する実験に扮いては（図 2)，短期間の宇宙飛 行で生じる血漿量減少（約-10\%）（2,3）と同程度にな るよう利尿薬：フロセミド $0.2 \mathrm{mg} / \mathrm{kg}$ を投与し，血液濃 縮を伴ら中心循環の血液量減少状態をつくった。その際, 脱水の程度の確認として，採血したへモグロビン濃度と ヘマトクリットの変化から Dill の予測式を用いて失われ た血漿量を算出した (8)。

一方，全血液量が減少した状態の模擬には下半身陰圧 負荷装置を使用した（図 3）。下半身陰圧負荷装置とは， 腰から下をシールドしたチャンバー内を陰圧にすること で，仰臥位のままでも体液分布の下方シフトにより中心 循環の血液量減少を生じさせることができる装置であ る。な抏，中心循環の血液量減少の評価のため，中心静 脈カテーテルを挿入し中心静脈圧も測定することで，陰 圧負荷の強度を 1 週間の宇宙飛行後に生じると推定され る中心静脈圧の変化量（約 $3 \sim 4 \mathrm{mmHg}$ 減少）(9）と同程 度になるよう調節した。 


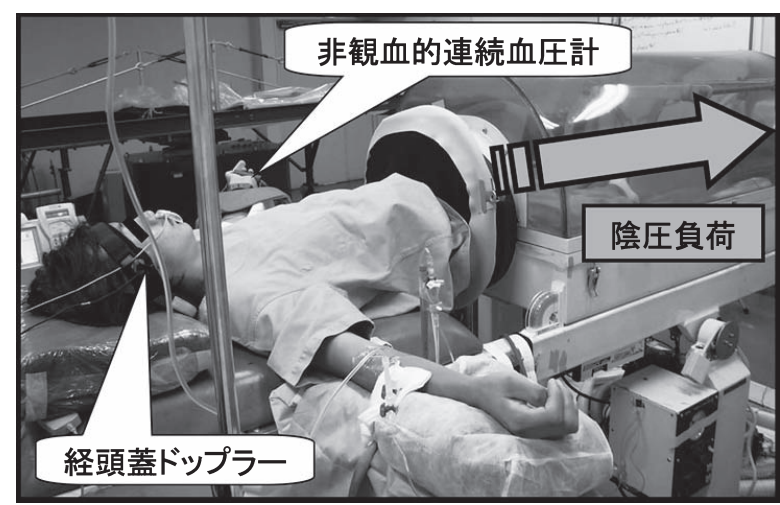

図 3 下半身陰圧負荷による中心循環の血液量減少の実験風景

両実験ともに，評価指標としての脳循環調節機能は， 被験者に装着した非観血的連続血圧計と経頭蓋ドップ ラーから一心拍ごとの動脈圧と脳血流速度を求め, 「血圧 から脳血流への伝わりの程度」を周波数解析および伝達 関数解析により算出, 定量化している。この「伝わりの 程度 : Gain $(\mathrm{cm} / \mathrm{s} / \mathrm{mmHg}) 」$ は, 血圧 $(\mathrm{mmHg})$ の変化に 対して脳血流速度 $(\mathrm{cm} / \mathrm{s})$ がぞの程度影響を受けたかを 意味している。すなわち, 值が ‘小さい’ 程, 調節機能 が増強されたと解釈でき，体循環調節機能が障害を受け た場合などでも，より安定した脳循環を維持することが 可能となる。

短期間の宇宙飛行による中心循環の血液量減少を想定 したこれら二つの状態の模擬からなる地上実験の仮説と して，利尿薬投与による脱水ならびに下半身陰圧負荷を 用いた両実験での結果が共に「脳循環調節機能の増強」 を示したならば，それは「中心循環の血液量減少」その ものが宇宙飛行による敛循環変化の要因として考兄ら る。一方, 両実験で得られた結果が異なり, 片方の久が 「脳循環調節機能の増強」を示したならば, 両実験間での 状態の違い，つまり中心循環の血液量減少に伴う「血液 性状の違い（血液濃縮の有無）」が宇宙飛行による脳循環 変化の主な要因であると考えられる。

上記の仮説を基にこれらの地上実験を実施した結果， 利尿薬投与による血漿量減少に起因する血液濃縮を伴っ た中心血液量減少状態, つまり脱水では「伝わりの程度: Gain $(\mathrm{cm} / \mathrm{s} / \mathrm{mmHg}) 」$ が有意に低下し, 脳循環調節機能の 増強が認められた $(5,6)$ 。一方, 下半身陰圧負荷により全 血液量の減少を模擬した中心血液量減少状態では脳循環 調節機能の変化は認められなかった (7)。これらの研究 結果は中心循環の血液量減少に伴う「血液濃縮」が脳循 環調節機能の増強に関与していることを示唆している。

先のスペースシャトル Neurolab-Mission（STS-90）に おいても, 同様な解析手法により脳循環調節機能を評価 し，2 週間の宇宙飛行中および帰還直後では「伝わりの 程度 : Gain $(\mathrm{cm} / \mathrm{s} / \mathrm{mmHg}) 」$ の低下，つまりは脳循環調節 機能の増強を認めている。さらにこの研究では, 帰還後
表 1 地上での各実験結果と宇宙実験結果との比較

\begin{tabular}{lccc}
\hline & 利尿薬投与 & $\begin{array}{c}\text { 下半身 } \\
\text { 陰圧負荷 }\end{array}$ & $\begin{array}{c}\text { 短期間の } \\
\text { 宇宙飛行 }\end{array}$ \\
\hline 中心循環の血液量 & 減少 & 減少 & 減少 \\
血液濃縮 & 有り & 無し & 有り $/$ 無し* \\
脳循環調節機能 & 増強 & 変化無し & 増強 \\
\hline
\end{tabular}

*スペースシャトル Neurolab-Mission（STS-90）飞おいては，脳 循環調節機能の変化と血液性状の変化（血液濃縮の有無）と の関連については検討されていない。

の検査において立位失神を呈した宇宙飛行士は存在して いない(1)。以上の研究結果を踏まえると，2週間の宇宙 飛行による血液濃縮を伴ら状態（軽度な脱水）が脳循環 調節機能の増強を導き（表 1 ), 中心血液量の低下や体循 環調節機能の低下に伴う起立耐性低下に拮抗した可能性 が推察される。実際には前庭神経系など他の因子も複合 的に関与しているが, 微小重力環境曝露による脳循環調 節機能の変化を検討する上で，血液濃縮の有無が重要な 要因の一つであると考兄らる。

現在, ISS においては数ヶ月に及ぶ長期宇宙滞在が行わ れている。しかし実際に ISS での長期宇宙滞在による脳循 環調節機能変化は検討されていない。そのため, ISS で の長期宇宙滞在においても，前出の 2 週間の宇宙飛行実 験（STS-90）(1) ならびに短期間の宇宙飛行による状態を 模擬した各地上実験 (5-7) での脳循環調節機能に関する 結果と同様の結果を示すか否かについては不明である。

そこで我々の研究グループでは, 2 週間の宇宙滞在が脳 循環調節機能に及ぼす影響に関する研究結果の再現性, ならびに長期宇宙滞在が及ぼす影響について検討するこ とを目的にISSにおける宇宙医学実験を計画した。昨年, その実験課題「長期宇宙滞在がヒトの脳循環調節機能に 及ぼす影響」が『ISS 利用ライフサイエンス及び宇宙医 学分野の国際公募研究』にて採択され, 現在, 研究実施 に向けてアメリカ航空宇宙局（National Aeronautics and Space Administration: NASA）や欧州宇宙機関（European Space Agency: ESA）などとの調整を行らとともに，地上 品を使用しての予備実験等を実施している。数年先には 長期宇宙滞在がヒトの脳循環調節機能に及ぼす影響に関 する研究の結果報告が出来る予定である。

\section{起立耐性と温熱環境}

我々の地上での生活に执いても，暑熱環境下，すなわ ち深部体温が上昇するような環境では，起立耐性低下が 顕著となる $(10,11)$ 。この暑熱により起立耐性が低下寸 ることを理解しておくことは，例えば，高温環境の下， 立位での作業時に打ける熱失神のリスクの把握やその予 防措置としての全身皮膚冷却の応用など，より安全な労 働衛生環境の構築を考えるらえでも重要なことである。 なお，その要因については一連の先行研究により検討さ 
れて打り, 肺動脈楔入圧 (12) や脳血管コンダクタンス （脳血流の流れやすさの指標）の低下 (13), フランク - ス ターリング曲線の変力シフト（12）など, これら心循環機 能に影響を及ぼす諸要因が，暑熱環境下に打ける起立耐 性低下に関係している可能性が示唆されている。

宇宙船内にける温熱環境は上述の微小重力環境, 宇宙 放射線環境，閉鎖環境など宇宙特有の特殊環境とは異な り, 約 $18 \sim 29^{\circ} \mathrm{C}$ 程度で一定の範囲内（各宇宙船により その範囲は若干異なる）に保たれて打り，船内の温熱環 境が生体に及ぼす影響は地上での温熱環境変化による影 響と比較すると小さいものと予想される。ただし温熱環 境が顕著に変化する場面として, 大気圈突入から帰還時 に打けるシャトル内の温度変化などがあげられる。宇宙 ステーションと同様にスペースシャトルのキャビン内に 打ける温度環境にも管理基準が設けられており，上層の フライトデッキ内に颃いては $24^{\circ} \mathrm{C}$ 以下となるように制 御されているが，下層のミッドデッキについてはそこま での温度制御はされていない。また，帰還用スーッ内部 の温度環境についても高温となり, 宇宙飛行士の深部体 温は約 $0.5^{\circ} \mathrm{C}$ 上昇することがあるとの報告もある $(14)$ 。

そこで，これまでにも帰還時にみられる起立耐性低下 への予防措置として, 帰還用スーッ内に着用した Liquid Cooling Garments（LCG : 衣服内にあるチューブに冷水を 還流させる）による全身皮膚冷却が用いられることがあ り，これは宇宙医学に基づいた人工的温熱環境の積極的 利用といえる。実際, 宇宙飛行後の起立耐性低下に対す る LCG の効果を検証した宇宙医学研究として, 1997 年 以前の 27 ミッションに拈いて, LCG 着用 63 名, 非着用 70 名にわたる宇宙飛行士の内, 帰還時に失神前駆症状を 呈した 17 名中 15 名が LCG 非着用であった（15）。また， 大気圈再突入から着陸直後の立位への姿勢変化時におい て，LCG 着用の有無による生理的データの違いを比較し た実験では, LCG を着用した宇宙飛行士の心拍数は, 非 着用群のそれに比べて, 再突入後の最大重力を受ける区 間から, 着陸直後の立位への姿勢変化時まで有意に低值 を示した (16)。

このように，身体を冷却することにより起立耐性低下 を防ぐことは経験則となっているが, 温熱環境の変化(暑 熱や寒冷環境）による起立耐性の変化とその要因のすべ てについては，未だ明らかになっていない。そこで我々 の研究グループでは, 上述の中心循環血液量の変化と脳 循環調節機能の関係に焦点をあて, 暑熱および冷却負荷 時のそれらの応答についての地上実験を体系的に実施し てきている。

暑熱負荷に関する実験として, 大気圈再突入から帰還 時に予想される深部体温上昇（14）と同程度となるよう に，被験者に着用させた温水還流服内に（図 4), 約 $45 \sim$ $47^{\circ} \mathrm{C}$ の温水を還流させる全身加温を約 40 分間負荷し た。また同様の全身加温の後, 下半身陰圧負荷装置を用 い，仰臥位のままで体液分布の下方シフトによる中心循 環の血液減少（立位状態を模擬）を生じさせた。なお同

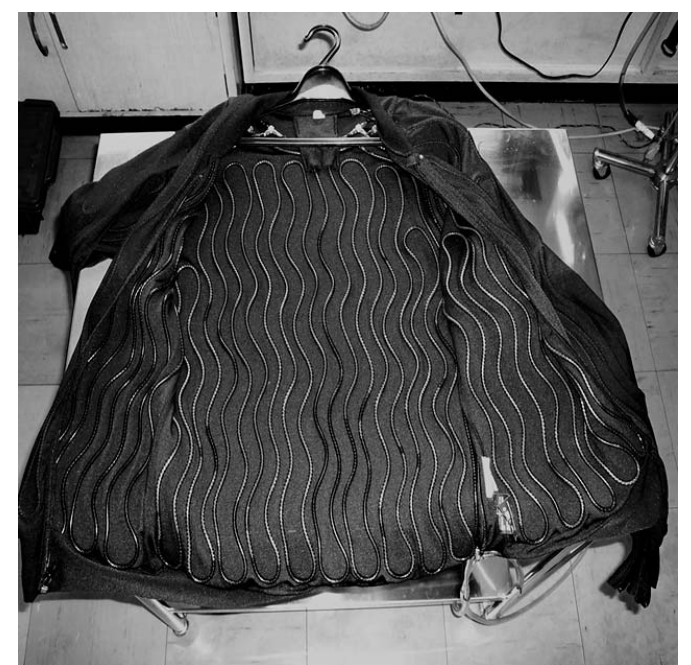

図4 地上での実験に用いている温水還流服（上半身）の画像。 生地に縫い付けられているチューブ内を温水が還流するように なっている。

一被験者に打いて，同一の実験を時間帯の異なる午前 8 時（朝）と午後 5 時（夕方）の 2 回，実験日をかえて実 施した。脳循環調節機能の評価指標については，前項で 記載したのと同様の解析方法により，「伝わりの程度 : Gain $(\mathrm{cm} / \mathrm{s} / \mathrm{mmHg})\rfloor$ 等を用いた。

これらの実験を実施した結果，全身加温により朝およ び夕方ともに深部体温は約 $0.5^{\circ} \mathrm{C}$ 上昇し, 脳血流量は有 意に減少した。一方，この発汗等による水分損失を伴う 状態での「伝わりの程度 : Gain $(\mathrm{cm} / \mathrm{s} / \mathrm{mmHg}) 」$ は, 夕方 においてのみ有意に低下し脳循環調節機能の増強が認め られた（17）。さらに全身加温に加えて下半身陰圧負荷を 実施した場合の負荷継続可能時間（起立耐性の度合いの 指標）は，朝に比べて夕方の医らが有意に長くなった (18)。これらのことから脳循環調節機能の増強は, 暑熱 環境曝露により脳血流の供給量が減少している状況下で の起立耐性低下に対抗する因子の一つであると考兄られ る。引き続き, このよらな脳循環調節機能の増強や起立 耐性の維持が，なぜ夕方においてのみ見られるのかにつ いての機序解明には，さらに検討を必要とするところで ある。しかしながら，この研究により得られた結果は地 上での生活において, より安全な労衝衛生環境の構築を 考えるらえでは有益な情報であると考えられる。また現 在，起立耐性低下を防ぐのに有用とされている身体冷却 (冷却負荷) に対する脳循環調節の変化とその日内変動特 性についても検討している。な报，宇宙飛行士において は光環境や生活サイクルの違いなどから，地上での生体 リズムとのズレ，あるいは異なるリズム環境への適応が 生じていると予想され, 現時点でこの研究結果を直接, 利用することは難しいが，今後，長期宇宙滞在時におけ る生体リズムの変化との関係も含めて検討していくこと も課題の一つである。 


\section{おわりに}

近年, 日本人宇宙飛行士の ISS 同時滞在での活動の様 子など，頻繁にメディアを通して拎の間でも目にする 機会が増えてきている。その点に打いては，宇宙が我々 により身近になってきているものと思われる。一方で， 実際に宇宙空間に出た時，滞在中さらには地球に帰還し た時に，人間の身体がぞのように変化や適応・再適応し， またどのような影響を被るのかについての話題を，一般 の情報として見聞きすることは少ない。

本稿では, 宇宙飛行から地球への帰還時にみられる起 立耐性の低下とそれに関係する可能性のある要因を中心 に述べてきたが，この現象と要因だけをとってみても， 宇宙での滞在期間による違いがあるのか，その場合どの ような機序によるものか等，未だ明らかになっていない ことがいくつか存在する。このような状況下に打いても, 実際に宇宙での人間（宇宙飛行士）が対象となる研究で は，その機会や資源（物理的，時間的，金銭的等）の限 られる中で遂行していくこととなるが，地上実験ととも に体系的にアプローチしていくことが，ょり有用な研究 成果を積み重㸚ていく上で重要であると考えている。

実際，宇宙空間は極限の環境であり，そこで働く飛行 士の健康をまもる宇宙医学は「究極の予防医学」と言光, その中での課題を解決していくことは, 決して宇宙医学 の久ならず，我々の地上での生活に影響する課題にも応 用・還元できることが期待される。すなわち，それらは 衛生学研究として意義のあるものだと考えている。そし て今後, 衛生学研究に拈ける宇宙医学分野での課題解決 に加えて，より多くの方に，それらに関連した見識を深 めていただけるよう，我々の一連の活動を遂行していく つもりである。

な沶, 本稿は第 80 回日本衛生学会学術集会の宇宙医学 連携研究会企画シンポジウムに扣いて発表したものに, 加筆した総説である。

本稿で紹介した我々の研究は, 括もに独立行政法人宇 宙航空研究開発機構 (JAXA) 関連一第 7 回および 9 回宇 宙環境利用に関する公募地上研究（日本宇宙フォーラ ム), ISS 利用ライフサイエンス及び宇宙医学分野の国際 公募研究, 文部科学省科学研究費補助金（課題番号 18700537 および21700659)などにより実施されているも のである。

\section{文献}

(1) Iwasaki K, Levine BD, Zhang R, Zuckerman JH, Pawelczyk JA, Diedrich A, et al. Human cerebral autoregulation before, during and after spaceflight. J Physiol. 2007;579:799-810.

(2) Watenpaugh DE, Hargens AR. The cardiovascular system in microgravity. In: Fregly MJ, Blatteis CM, eds. Handbook of Physiology: Environmental Physiology. Bethesda, MD: Am. Physiol. Soc. 1996:631-674.
(3) Fritsch-Yelle JM, Whitson PA, Bondar RL, Brown TE. Subnormal norepinephrine release relates to presyncope in astronauts after spaceflight. J Appl Physiol. 1996;81: 2134-2141.

(4) Smith SM. Red blood cell and iron metabolism during space flight. Nutrition. 2002;18:864-866.

（5）小川洋二郎, 青木 健, 斉藤崇史, 西村直子, 曷川 元，岩崎賢一. 2 週間の宇宙飛行相当の脱水が脳循環 に及活寸影響. 日本衛生学雑誌 2009;64:475.

(6) Ogawa Y, Iwasaki K, Aoki K, Saitoh T, Kato J, Ogawa, S. Dynamic cerebral autoregulation after mild dehydration to simulate microgravity effects. Aviat Space Environ Med. $2009 ; 80: 443-447$

( 7 ) Ogawa Y, Iwasaki K, Aoki K, Shibata S, Kato J, Ogawa S. Central hypovolemia with hemodilution impairs dynamic cerebral autoregulation. Anesth Analg. 2007;105:13891396.

( 8 ) Dill DB, Costill DL. Calculation of percentage changes in volumes of blood, plasma, and red cells in dehydration. $\mathrm{J}$ Appl Physiol. 1974;37:247-248.

( 9 ) Convertino VA, Doerr DF, Ludwig DA, Vernikos J. Effect of simulated microgravity on cardiopulmonary baroreflex control of forearm vascular resistance. Am J Physiol. 1994; 266:R1962-1969.

(10) Allan JR, Crossley RJ. Effect of controlled elevation of body temperature on human tolerance to $+\mathrm{G} \mathrm{z}$ acceleration. J Appl Physiol. 1972; 33:418-420.

(11) Lind AR, Leithead CS, McNicol GW. Cardiovascular changes during syncope included by tilting men in the heat. J Appl Physiol. 1968;25:268-276.

(12) Wilson TE, Brothers RM, Tollund C, Dawson EA, Nissen P, Yoshiga CC, Jons C, Secher NH, Crandall CG. Effect of thermal stress on Frank-Starling relations in humans. J Physiol. 2009; 587:3383-3392.

(13) Wilson TE, Cui J, Zhang R, Crandall CG. Heat stress reduces cerebral blood velocity and markedly impairs orthostatic tolerance in humans. Am J Physiol Regul Integr Comp Physiol. 2006;291:R1443-1448.

(14) Pawelczyk JA, Rimmer DW. Cold stimulation to improve orthostatic tolerance. In proceedings of Bioastronautics Investigators Workshop; 2001 January 17-19; Galveston, TX. Houston, TX: Universities Space Research Association Division of Space Life Sciences ; $2001: 1-17$.

(15) Roger B, Daniel K. The effect of liquid cooling garments on post-space flight orthostatic intolerance. The sixth annual conference of the international space university; $1997 ; 125$.

(16) Perez SA, Charles JB, Fortner GW, Hurst V 4th, Meck JV. Cardiovascular effects of anti-G suit and cooling garment during space shuttle re-entry and landing. Aviat Space Environ Med. 2003;74:753-757.

（17）青木 健，小川洋二郎，斉藤崇史，西村直子，曷川 元，岩崎賢一. 水分損失を伴ら温熱刺激に対する脳循 環変化の日内変動特性. 日本衛生学雑誌 2009;64:476.

（18）青木 健，小川洋二郎，岩崎賢一．温熱負荷に対する 圧受容器反射機能拈よび脳血流速度の日内変動. 日本 衛生学雑誌 2008; 63:466. 